\title{
BMJ
}

\section{Use of angiotensin receptor blockers and risk of dementia in a predominantly male population: prospective cohort analysis}

\author{
Nien-Chen Li, statistician, ${ }^{1,2}$ Austin Lee, senior statistician, ${ }^{2,3}$ Rachel A Whitmer, research epidemiologist, ${ }^{4}$ \\ Miia Kivipelto, associate professor, ${ }^{5}$ Elizabeth Lawler, epidemiologist, ${ }^{6}$ Lewis E Kazis, professor, ${ }^{1,2}$ \\ Benjamin Wolozin, professor 2,7
}

${ }^{1}$ Center for the Assessment of

Pharmaceutical Practices and

Pharmaceutical Assessment,

Management and Policy Program,

Department of Health Policy and

Management, Boston University

School of Public Health, Boston,

MA, USA

${ }^{2}$ Center for Health Quality

Outcomes and Economic

Research, Veteran Affairs Medical

Center, Bedford, MA

${ }^{3}$ Department of Surgery,

Massachusetts General Hospital, Boston, MA

${ }^{4}$ Division of Research,

Epidemiology, Etiology and

Prevention, Kaiser Permanente, Oakland, CA, USA

${ }^{5}$ Aging Research Center, Karolinska Institute, Stockholm,

Sweden

${ }^{6}$ MAVERIC, VA Cooperative

Studies Program, Boston, MA

${ }^{7}$ Department of Pharmacology and Department of Neurology, Boston University School of

Medicine, Boston, MA 02118

2526, USA

Correspondence to:

bwolozin@bu.edu

Cite this as: $B M J$ 2010;340:b5465 doi:10.1136/bmj.b5465

\section{ABSTRACT}

Objective To investigate whether angiotensin receptor blockers protect against Alzheimer's disease and dementia or reduce the progression of both diseases. Design Prospective cohort analysis.

Setting Administrative database of the US Veteran Affairs, 2002-6.

Population 819491 predominantly male participants (98\%) aged 65 or more with cardiovascular disease.

Main outcome measures Time to incident Alzheimer's disease or dementia in three cohorts (angiotensin receptor blockers, lisinopril, and other cardiovascular drugs, the "cardiovascular comparator") over a four year period (fiscal years 2003-6) using Cox proportional hazard models with adjustments for age, diabetes, stroke, and cardiovascular disease. Disease progression was the time to admission to a nursing home or death among participants with pre-existing Alzheimer's disease or dementia.

Results Hazard rates for incident dementia in the angiotensin receptor blocker group were 0.76 (95\% confidence interval 0.69 to 0.84 ) compared with the cardiovascular comparator and 0.81 (0.73 to 0.90 ) compared with the lisinopril group. Compared with the cardiovascular comparator, angiotensin receptor blockers in patients with pre-existing Alzheimer's disease were associated with a significantly lower risk of admission to a nursing home $(0.51,0.36$ to 0.72$)$ and death $(0.83,0.71$ to 0.97$)$. Angiotensin receptor blockers exhibited a dose-response as well as additive effects in combination with angiotensin converting enzyme inhibitors. This combination compared with angiotensin converting enzyme inhibitors alone was associated with a reduced risk of incident dementia $(0.54,0.51$ to 0.57$)$ and admission to a nursing home $(0.33,0.22$ to 0.49$)$. Minor differences were shown in mean systolic and diastolic blood pressures between the groups. Similar results were observed for Alzheimer's disease.

Conclusions Angiotensin receptor blockers are associated with a significant reduction in the incidence and progression of Alzheimer's disease and dementia compared with angiotensin converting enzyme inhibitors or other cardiovascular drugs in a predominantly male population.

\section{INTRODUCTION}

Dementia, including Alzheimer's disease, is one of the major threats to public health as people age. Dementia is also an important economic cost to society because affected people may spend extended periods in nursing homes. The causes of dementia, and Alzheimer's disease in particular, are complex, but evidence increasingly points to three main risk factors-age, the accumulation of amyloid $\beta$ in the brain, and the deterioration of the cardiovascular system. Cardiovascular dysfunction is also strongly related to other forms of dementia. Studies have found that cardiovascular risk factors in mid-life, such as hypercholesterolaemia, hypertension, and diabetes contribute to the development of dementia. ${ }^{1-5}$ Drugs used to treat these risk factors may also reduce the incidence of dementia. ${ }^{6-11}$

Pharmacotherapy targeting the renin-angiotensin system is one of the most effective means of reducing hypertension and cardiovascular morbidity. ${ }^{12} 13$ Renin is a protease that cleaves angiotensinogen to produce angiotensin I, which is then cleaved by angiotensin converting enzyme to produce the bioactive peptide angiotensin II. ${ }^{14}$ Angiotensin II binds to multiple receptors, with the AT1 and AT2 receptors being the best studied and most abundant angiotensin II receptors in the vasculature. Both receptors are present in brain and vasculature. ${ }^{15}$ They seem to function in opposition. ${ }^{16}$ The mechanism of action of AT2 receptors remains to be fully elucidated, but in the rat the receptors inhibit endothelial cell proliferation and promote axonal regeneration. ${ }^{17} 18$

Multiple studies have shown that angiotensin converting enzyme inhibitors prevent the action of angiotensin II and are the most effective agents for lowering blood pressure. ${ }^{1213}$ Their efficacy has led to this class of drugs being designated as a primary treatment for hypertension. These drugs are also associated with lower rates of congestive heart failure, myocardial 
Table 1|Personal details of participants analysed in study. Values are numbers (percentages) unless stated otherwise

\begin{tabular}{|c|c|c|c|c|c|c|}
\hline \multirow[b]{2}{*}{ Variables } & \multicolumn{3}{|c|}{ Alzheimer's disease $(n=819491)$} & \multicolumn{3}{|c|}{ Dementia (n=799 069) } \\
\hline & $\begin{array}{l}\text { Angiotensin receptor } \\
\text { blocker }(n=11703)\end{array}$ & $\begin{array}{l}\text { Lisinopril } \\
(n=93484)\end{array}$ & $\begin{array}{l}\text { Cardiovascular comparator } \\
\qquad(n=714304)\end{array}$ & $\begin{array}{l}\text { Angiotensin receptor } \\
\text { blocker }(n=11507)\end{array}$ & $\begin{array}{l}\text { Lisinopril } \\
(n=91164)\end{array}$ & $\begin{array}{l}\text { Cardiovascular comparator } \\
\qquad(\mathrm{n}=696398)\end{array}$ \\
\hline Mean (SD) age (years) & $74(5.5)$ & $74(5.6)$ & $75(5.9)$ & $74(5.5)$ & $74(5.5)$ & $75(5.9)$ \\
\hline \multicolumn{7}{|l|}{ Race: } \\
\hline Hispanic, white & $101(0.9)$ & $2872(3.1)$ & $14088(2.0)$ & $96(0.8)$ & $2729(3.0)$ & $13395(1.9)$ \\
\hline Hispanic, black & $6(0.05)$ & $209(0.22)$ & $1168(0.16)$ & $6(0.05)$ & $200(0.22)$ & $1132(0.16)$ \\
\hline Native American Indian & $8(0.07)$ & $88(0.09)$ & $653(0.09)$ & $8(0.07)$ & $85(0.09)$ & $638(0.09)$ \\
\hline Black & $232(2.0)$ & $2398(2.6)$ & $31374(4.4)$ & $222(1.9)$ & $2240(2.5)$ & $29816(4.3)$ \\
\hline Asian & $35(0.3)$ & $210(0.2)$ & $1285(0.2)$ & $35(0.3)$ & $200(0.2)$ & $1222(0.2)$ \\
\hline White & $3157(27)$ & $28976(31)$ & $256442(36)$ & $3087(27)$ & $28082(31)$ & $248607(36)$ \\
\hline Unknown & $8164(70)$ & $58731(63)$ & $409294(57)$ & $8053(70)$ & $57628(63)$ & $401588(58)$ \\
\hline Men & $11392(97)$ & $91881(98)$ & $701201(98)$ & 11205 (97) & $89641(98)$ & $683690(98)$ \\
\hline Women & $311(3)$ & $1603(2)$ & $13103(2)$ & $302(3)$ & $1523(2)$ & $12708(2)$ \\
\hline \multicolumn{7}{|l|}{ Diseases: } \\
\hline Hypertension & 10857 (93) & $85441(91)$ & $571673(80)$ & $10676(93)$ & $83324(91)$ & $557617(80)$ \\
\hline Cardiovascular disease & $3967(34)$ & $28087(30)$ & $357331(50)$ & $3886(34)$ & $27218(30)$ & $347973(50)$ \\
\hline Diabetes & $4090(35)$ & $38731(41)$ & $151945(21)$ & $4020(35)$ & $37784(41)$ & $147687(21)$ \\
\hline Stroke & $1449(12)$ & $12776(14)$ & $114183(16)$ & $1390(12)$ & $11933(13)$ & $107554(15)$ \\
\hline Blood pressure*: & $n=1078$ & $n=5439$ & $n=45978$ & $\mathrm{n}=988$ & $n=5012$ & $n=42843$ \\
\hline Mean (SD) systolic blood pressure & $136(13)$ & $134(13)$ & $133(14)$ & $136(13)$ & $134(13)$ & $133(14)$ \\
\hline Mean (SD) diastolic blood pressure & $74(8)$ & $73(8)$ & $71(8)$ & $74(8)$ & $73(8)$ & $72(8)$ \\
\hline
\end{tabular}

*Subsample of patients from Veteran Affairs Vertically Integrated Service Network 1.

ischaemia, renal disease, and death than hypertensive drugs acting through other mechanisms. ${ }^{12}{ }^{13}$ Two small studies found that angiotensin converting enzyme inhibitors reduced rates of cognitive decline..$^{1920}$

Drugs that selectively inhibit the AT1 receptor are termed angiotensin receptor blockers. These drugs reduce blood pressure and protect against cardiovascular outcomes such as myocardial infarction and atrial fibrillation although with slightly less efficacy than angiotensin converting enzyme inhibitors. ${ }^{12} 13$ Angiotensin receptor blockers also protect against diabetes, possibly with greater efficacy than angiotensin converting enzyme inhibitors. ${ }^{21-23}$ The Valsartan Heart Failure Trial (Val-HeFT) suggested that angiotensin receptor blockers and angiotensin converting enzyme inhibitors exhibit added benefit for cardiovascular outcomes when used in combination, but this was not observed in the Candesartan in Heart Failure: Assessment of Reduction in Mortality and Morbidity (CHARM) study. ${ }^{2425}$ An increasing number of studies have shown a relation between angiotensin receptor blockers and preservation of cognitive function. ${ }^{26}$ Studies in both animals and humans found that angiotensin receptor blockers help to preserve cognitive function through a mechanism that is independent of the antihypertensive effects. ${ }^{27-31}$ Comprehensive summaries on the role of the reninangiotensin system in Alzheimer's disease and the effects on cognitive function of drugs that inhibit the renin-angiotensin system have been reviewed. ${ }^{3233} \mathrm{On}$ the basis of these data the effect of angiotensin receptor blockers and angiotensin converting enzyme inhibitors on dementia outcomes should be evaluated.
We investigated whether angiotensin receptor blockers protect against dementia and Alzheimer's disease and reduce the progression of these diseases in a large population with uniform healthcare coverage.

\section{METHODS}

This study used information from the Veterans health system decision support system database, which contains records on about 4.5 million people annually in the US Veterans Affairs health system from fiscal year 2002 (1 October 2001) to end of fiscal year 2006 (30 September 2006); over the five years of the study the records totalled about 7.3 million people. ${ }^{34}$ For studies of incident Alzheimer's disease and dementia we used records from the first year of the database, fiscal year 2002, as a baseline to ensure that participants were free of these diseases for at least one year, and we restricted the analytical part of the study to fiscal years 2003-6. The sample sizes were more than 11500 for the angiotensin receptor blockers group, more than 91000 for the lisinopril group, and more than 696000 for the cardiovascular comparator group; see web extra table 1 on bmj.com.

We included adults aged 65 or more as of 1 October 2002. Disease codes are those used in ICD-9 (international classification of diseases, ninth revision). The analysis of incidence was restricted to those without a previous diagnosis of Alzheimer's disease (code 331.0) or dementia $(291,294,331.0)$ as judged by an absence of the diagnosis from fiscal year 2002 or up to the point of initiation of the targeted drugs for participants who started taking the drugs after fiscal year 2002. We restricted the analysis of disease progression to those 

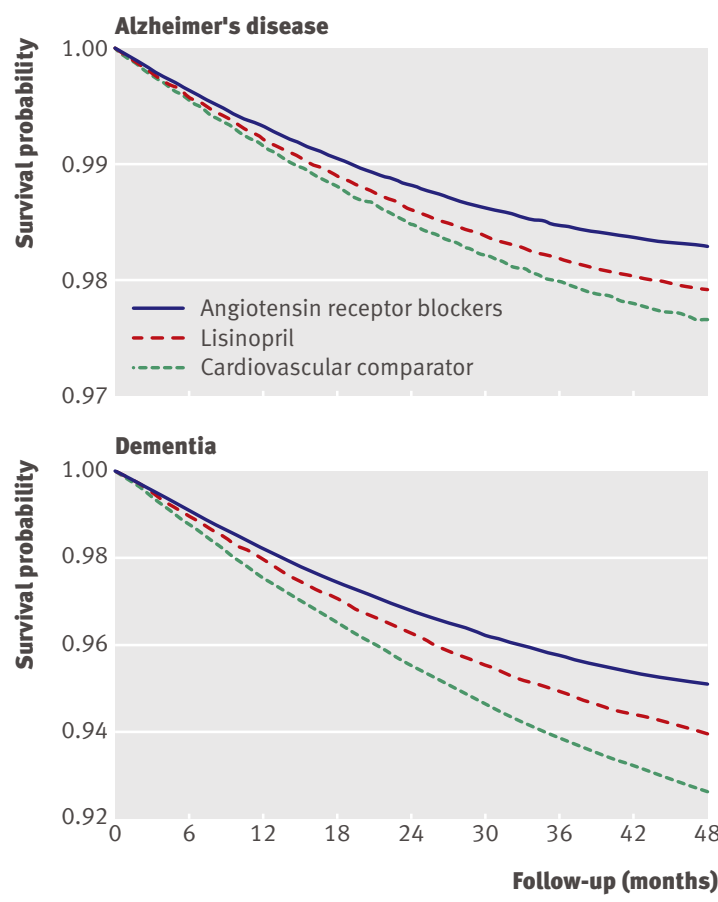

Fig 1| Survival function for incident Alzheimer's disease and incident dementia in study cohorts

with an existing diagnosis of Alzheimer's disease or dementia; only events after the diagnosis of dementia were used for the study of progression. To establish exclusion criteria we used a floating starting point. The time to event was measured from the first record of the drug to the occurrence of the event (diagnosis of dementia or Alzheimer's disease, nursing home admission, or death). For participants lacking events before the end of fiscal year 2006 we defined the time to event as censored.

\section{Comparators and models}

We examined three cohorts: those taking angiotensin receptor blockers, those taking the angiotensin converting enzyme inhibitor lisinopril, and those taking cardiovascular drugs (drugs with a "CV" designation in the Veterans Affairs formulary, excluding angiotensin receptor blockers, statins, and angiotensin converting enzyme inhibitors), the "cardiovascular comparator." The lisinopril group represents a comparator group of a similar drug class to that of angiotensin receptor blockers because of shared indications for use. We specifically selected lisinopril because it is has the largest group of users and longest history of use. To control for potential biases related to selection of one particular angiotensin converting enzyme inhibitor we also examined a comparator group of the cohort using other angiotensin converting enzyme inhibitors (see fig 3, table 5, and web extra table 5). We also examined a second group comprising people taking cardiovascular drugs other than angiotensin receptor blockers, the cardiovascular comparator group. We examined this group because overlap between the site of action of angiotensin converting enzyme inhibitors and angiotensin receptor blockers could mute a potentially beneficial effect of angiotensin receptor blockers. The cardiovascular comparator group contained people with similar morbidity profiles to that of the angiotensin receptor blocker group but comprised a much broader group of drugs than the angiotensin converting enzyme inhibitor group. We determined drug use on the basis of two criteria: a drug possession ratio of $80 \%$ or greater for the respective drug during the six months after entry into the study, and no exposure to the other study drugs on entry and during the first six months of the study. We carried out secondary analyses on outcomes in people who switched from angiotensin converting enzyme inhibitors to angiotensin receptor blockers, or vice versa, and the dose-response profiles for angiotensin receptor blocker use.

The study design used multiple strategies to deal with potential sources of bias. To avoid bias due to misclassification we chose cohorts who shared similar health profiles. Lisinopril and angiotensin receptor blockers are both antihypertensives that modulate angiotensin signalling. Drugs used by the cardiovascular comparator included $\beta$ blockers and calcium channel antagonists. To investigate bias arising from differences in comorbidities and health profiles we compared risk factors for each cohort; these were similar between the groups (table 1). Because data on blood pressure were not available from the national Veteran Affairs decision support system database at the time of this study, we determined mean blood pressures for each cohort on the basis of a subsample from the Veterans Affairs health system vertically integrated service network. We randomly sampled eight values each for systolic and diastolic blood pressure for all the people from each cohort in the Vertically Integrated Service Networks 1,2 , and 3 , as a subset analysis and then determined mean systolic and diastolic values for each patient. To avoid bias from reliance on prescription data we required participants to have a drug possession ratio of $80 \%$ or greater. High possession ratios imply that patients are using up their drugs in the expected period of time, corresponding with consistent use of the drug. We examined losses to follow-up for each cohort. These did not differ (see web extra table 2).

Drug use after entry to the study was not restricted, except for the studies of additive effects and switching in which we controlled for exposure to drugs in the other two cohorts after entry into the study. Allowing for multiple exposure maintained adequate sample sizes for subgroup analyses and adequate statistical power. We also examined the data on disease progression using a model that excludes polypharmacy after entry to the study; using this approach we obtained similar effects for trend, but the changes did not achieve statistical significance given the inadequate power.

We examined multiple models. Firstly, we used age, stroke (code 430-434), hypertension (401-405, and 459.3), cardiovascular disease $(429.2,410-414,428$, 430-438, and 440), and diabetes (250) as covariates. 
Table 2 |Cox proportional hazard model for association between angiotensin receptor blockers and incidence of Alzheimer's disease or dementia

\begin{tabular}{|c|c|c|c|c|c|c|}
\hline \multirow[b]{2}{*}{ Variables } & \multicolumn{3}{|c|}{ Incidence of Alzheimer's disease } & \multicolumn{3}{|c|}{ Incidence of dementia } \\
\hline & Estimate (SE) & $P$ value & Hazard rate $(95 \% \mathrm{Cl})$ & Estimate (SE) & $P$ value & Hazard rate* $(95 \% \mathrm{Cl})$ \\
\hline $\begin{array}{l}\text { Angiotensin receptor blocker } \\
v \text { lisinopril }\end{array}$ & $-0.213(0.089)$ & 0.016 & 0.81 (0.68 to 0.96$)$ & $-0.207(0.053)$ & $<0.001$ & $0.81(0.73$ to 0.90$)$ \\
\hline $\begin{array}{l}\text { Angiotensin receptor blocker } \\
v \text { cardiovascular comparator }\end{array}$ & $-0.171(0.085)$ & 0.045 & $0.84(0.71$ to 1.00$)$ & $-0.269(0.051)$ & $<0.001$ & $0.76(0.69$ to 0.84$)$ \\
\hline $\begin{array}{l}\text { Lisinopril } v \text { cardiovascular } \\
\text { comparator }\end{array}$ & $0.043(0.029)$ & 0.145 & $1.04(0.99$ to 1.11$)$ & $-0.061(0.017)$ & 0.0004 & 0.94 (0.91 to 0.97$)$ \\
\hline Age & $0.101(0.001)$ & $<0.001$ & 1.11 (1.10 to 1.11$)$ & $0.087(0.001)$ & $<0.001$ & 1.09 (1.09 to 1.09$)$ \\
\hline Cardiovascular disease & $-0.011(0.017)$ & 0.505 & 0.99 (0.96 to 1.02$)$ & $0.062(0.010)$ & $<0.001$ & 1.06 (1.04 to 1.09$)$ \\
\hline Diabetes & $0.039(0.020)$ & 0.049 & $1.04(1.00$ to 1.08$)$ & $0.158(0.011)$ & $<0.001$ & $1.17(1.15$ to 1.20$)$ \\
\hline Stroke & $0.694(0.018)$ & $<0.001$ & 2.00 (1.93 to 2.07$)$ & $0.940(0.010)$ & $<0.001$ & $2.56(2.51$ to 2.61$)$ \\
\hline
\end{tabular}

*Adjusted for age, stroke, cardiovascular disease, and diabetes.

We removed hypertension when we observed no significant covariation in the multivariate model. Because angiotensin receptor blockers are often prescribed to people with renal insufficiency, we examined a separate model incorporating renal disease as a covariate; people with renal insufficiency were defined as those with glomerular filtration rates of less than $60 \mathrm{ml} / \mathrm{min}$ using a formula defined by the Renal Disease Study Group. $^{35}$

\section{Outcomes}

For the analysis of disease progression we studied the time to admission to a nursing home or death. Previous clinical studies have successfully used new medical diagnoses or events as proxies for progression of $\mathrm{Alz}-$ heimer's disease. Time to being admitted to institutional care, for example, has been used as a criterion for evaluation of the clinical efficacy of putative therapeutics for Alzheimer's disease in multiple prospective clinical trials. ${ }^{36-39}$ Death is also a robust criterion for progression of Alzheimer's disease. ${ }^{363840}$ The demonstration of utility for time to admission to institutional care provides good support for the use of these measures as proxies for the progression of Alzheimer's disease in the current study. Outcomes of progressive disease were based on the well documented and validated Beneficiary and Identification Records Locator Subsystem files for occurrence of deaths that included date of recorded death, and Veteran Affairs nursing home files for date of being admitted to institutional care. All files were merged on unique identifiers using scrambled social security numbers and then stripped of these identifiers for confidentiality.

\section{Strategy for analysis}

We used Cox proportional hazard models to obtain hazard rates between the angiotensin receptor blocker group and comparators, which considers the time to events. Censoring was defined by three criteria: end of study (30 September 2006); losses to follow-up determined from three database files on clinic visits, diagnoses, and procedures; and death.

\section{Statistical analyses}

For all statistical calculations we used SAS version 9.01 software. Covariates for the Cox proportional hazard models were age, stroke, hypertension, cardiovascular disease, and diabetes. We carried out data management for missing values on covariates and the outcome variable (time to event). During the main study period (fiscal years 2003-6), we identified 6867768 patients from the diagnosis database. Only $6630(<0.1 \%)$ were missing date of birth. By selecting people aged 65 or older on 1 October 2002, those missing date of birth were automatically excluded. Covariates were coded as present (1) or absent (0) based on diagnoses during the study period. If disease codes for a particular condition were missing, we regarded the condition as absent (0). Outcomes were defined as time to events, and missing events would appear as time censored either as a result of end of study or losses to follow-up or death (with the exception of the study of progression, where death is defined as an event).

Point estimates and 95\% confidence intervals from Cox proportional hazards models are reported for the adjusted hazard rates. Outcomes for each cohort were plotted with a $\log (-\log ($ time $)) v \log$ (time) graph. The curves were parallel, validating the application of the Cox proportional hazards model. We also tested the Weibull model for a sensitivity analysis and obtained similar results.

\section{RESULTS}

After exclusions, 819491 participants were available for the study of incident Alzheimer's disease and 799069 for the study of incident dementia (table 1). The number of participants with existing Alzheimer's disease for the study of disease progression (admission to a nursing home) was 12574 (476 in the angiotensin receptor blocker group, 3227 in the lisinopril group, and 8871 in the cardiovascular comparator group, see web extra table 2) and with dementia was 44601 (1920 in the angiotensin receptor blocker group, 12064 in the lisinopril group, and 30617 in the cardiovascular comparator group). Overall, 12879 participants with Alzheimer's disease (491 in the 
Table $3 \mid$ Cox proportional hazard model for association between angiotensin receptor blockers and disease progression (admission to nursing home or death) among participants with Alzheimer's disease or dementia

\begin{tabular}{|c|c|c|c|c|c|c|}
\hline \multirow[b]{2}{*}{ Comparison groups } & \multicolumn{3}{|c|}{ Admission to nursing home } & \multicolumn{3}{|c|}{ Death } \\
\hline & Estimate (SE) & $P$ value & Hazard rate $(95 \% \mathrm{Cl})$ & Estimate (SE) & $P$ value & Hazard rate* $(95 \% \mathrm{Cl})$ \\
\hline \multicolumn{7}{|l|}{ Alzheimer's disease: } \\
\hline Angiotensin receptor blocker $v$ lisinopril & $-0.458(0.182)$ & 0.0119 & $0.63(0.44$ to 0.90$)$ & $-0.163(0.084)$ & 0.054 & $0.85(0.72$ to 1.00$)$ \\
\hline Angiotensin receptor blocker $v$ cardiovascular comparator & $-0.671(0.177)$ & 0.0001 & $0.51(0.36$ to 0.72$)$ & $-0.187(0.081)$ & 0.022 & $0.83(0.71$ to 0.97$)$ \\
\hline Lisinopril $v$ cardiovascular comparator & $-0.213(0.062)$ & 0.0006 & $0.81(0.72$ to 0.91$)$ & $-0.024(0.033)$ & 0.463 & $0.98(0.92$ to 1.04$)$ \\
\hline Age & $0.025(0.005)$ & $<0.001$ & $1.03(1.02$ to 1.04$)$ & $0.053(0.003)$ & $<0.001$ & 1.05 (1.05 to 1.06$)$ \\
\hline Cardiovascular disease & $0.235(0.055)$ & $<0.001$ & 1.27 (1.14 to 1.41$)$ & $-0.019(0.028)$ & 0.493 & $0.98(0.93$ to 1.04$)$ \\
\hline Diabetes & $0.347(0.053)$ & $<0.001$ & 1.41 (1.28 to 1.57$)$ & $0.096(0.029)$ & 0.001 & $1.10(1.04$ to 1.17$)$ \\
\hline Stroke & $0.556(0.052)$ & $<0.001$ & $1.74(1.57$ to 1.93$)$ & $0.016(0.029)$ & 0.595 & $1.02(0.96$ to 1.08$)$ \\
\hline \multicolumn{7}{|l|}{ Dementia: } \\
\hline Angiotensin receptor blocker $v$ lisinopril & $-0.308(0.084)$ & 0.0002 & $0.74(0.62$ to 0.87$)$ & $-0.139(0.044)$ & 0.001 & $0.87(0.80$ to 0.95$)$ \\
\hline Angiotensin receptor blocker $v$ cardiovascular comparator & $-0.491(0.081)$ & $<0.001$ & $0.61(0.52$ to 0.72$)$ & $-0.120(0.042)$ & 0.004 & 0.89 (0.82 to 0.96$)$ \\
\hline Lisinopril $v$ cardiovascular comparator & $-0.184(0.032)$ & $<0.001$ & 0.83 (0.78 to 0.89$)$ & $0.019(0.018)$ & 0.279 & $1.02(0.99$ to 1.06$)$ \\
\hline Age & $0.027(0.002)$ & $<0.001$ & $1.03(1.02$ to 1.03$)$ & $0.056(0.001)$ & $<0.001$ & $1.06(1.06$ to 1.06$)$ \\
\hline Cardiovascular disease & $0.326(0.031)$ & $<0.001$ & 1.39 (1.30 to 1.47$)$ & $0.026(0.016)$ & 0.112 & 1.03 (0.99 to 1.06$)$ \\
\hline Diabetes & $0.282(0.028)$ & $<0.001$ & $1.33(1.26$ to 1.40$)$ & $0.078(0.016)$ & $<0.001$ & $1.08(1.05$ to 1.12$)$ \\
\hline Stroke & $0.588(0.028)$ & $<0.001$ & $1.80(1.71$ to 1.90$)$ & $0.065(0.015)$ & $<0.001$ & 1.07 (1.04 to 1.10$)$ \\
\hline
\end{tabular}

*Adjusted for age, stroke, cardiovascular disease, and diabetes.

angiotensin receptor blocker group, 3333 in the lisinopril group, and 9055 in the cardiovascular comparator group) and 45724 with dementia (1980 in angiotensin receptor blocker group, 12483 in lisinopril group, and 31261 in the cardiovascular comparator group) were included in the study of mortality. The mean follow-up times are described in web extra table 3 . The characteristics of the groups used for analysis of Alzheimer's disease and for dementia were similar (table 1). The mean age of each group was 74 years, and the participants were largely men (98\%).

The prevalence of general cardiovascular disease and stroke was lower for the angiotensin receptor blocker and lisinopril groups than for the cardiovascular comparator, but the prevalence of diabetes was higher for the angiotensin receptor blocker and lisinopril groups than for the cardiovascular comparator (table 1), which is to be expected in routine care as both angiotensin receptor blockers and lisinopril are frequently prescribed for people with diabetes. Each of the differences in comorbid illnesses was statistically significant $(\mathrm{P}<0.001)$ because of the large number of people in each group. Mean systolic and diastolic blood pressures were similar between groups (table 1).

\section{Incident Alzheimer's disease and dementia}

Figure 1 shows the survival curves for incident Alzheimer's disease and dementia among participants in the three groups (see web extra table 1 for the unadjusted incident rates). Angiotensin receptor blockers were associated with significant reductions in incident Alzheimer's disease compared with lisinopril (hazard rate $0.81,95 \%$ confidence interval 0.68 to $0.96, \mathrm{P}=0.016$; table 2$)$ or the cardiovascular comparator $(0.84,0.71$ to $1.00, \mathrm{P}=0.045$; table 2). More participants developed incident dementia than incident Alzheimer's disease, although the results were similar to those for Alzheimer's disease. Angiotensin receptor blockers were also associated with significant reductions in incident dementia compared with lisinopril $(0.81,0.73$ to $0.90, \mathrm{P}<0.001)$ or the cardiovascular comparator $(0.76$, 0.69 to $0.84, \mathrm{P}<0.001$; table 2 ). Adding hypertension and renal insufficiency as covariates did not change the outcomes (data not shown).

\section{Admission to nursing homes and death}

Web table 2 shows the unadjusted rates for admission to nursing homes of people with Alzheimer's disease and death among patients with a diagnosis of Alzheimer's disease and dementia. From the Cox proportional hazards models users of angiotensin receptor blockers with Alzheimer's disease showed significantly lower rates of admissions to nursing homes $(0.51,0.36$ to $0.72, \mathrm{P}=0.0001)$ and death $(0.83,0.71$ to $0.97, \mathrm{P}=0.022)$ compared with users of the cardiovascular comparator drugs (table 3). Similar results were observed for patients with dementia (table 3).

Stroke was the strongest factor associated with disease incidence or admission to a nursing home but a weaker factor in relation to death (tables 2 and 3).

\section{Graded drug effects}

Sufficient numbers of participants used candesartan, irbesartan, losartan, or valsartan to study doseresponse effects (see web extra table 4). Each drug showed a clear dose-response relation, with higher doses associated with lower rates of incident dementia (table 4). For example, among participants in the high dose candesartan group the hazard rate for incident dementia was $27 \%$ lower than that in the low dose group. During the study the use of valsartan (and losartan) increased (see web extra fig 1). 
Table $4 \mid$ Effect of angiotensin receptor blocker dosage (high $v$ low) on incidence of dementia

\begin{tabular}{lccc} 
Angiotensin receptor blocker & Estimate $(\mathrm{SE})$ & P value & Hazard rate $(95 \% \mathrm{Cl})$ \\
Candesartan & $-0.322(0.076)$ & $<0.001$ & $0.73(0.62$ to 0.84$)$ \\
\hline Irbesartan & $-0.174(0.044)$ & $<0.001$ & $0.84(0.77$ to 0.92$)$ \\
\hline Losartan & $-0.200(0.066)$ & 0.0025 & $0.82(0.72$ to 0.93$)$ \\
\hline Valsartan & $-0.103(0.198)$ & 0.602 & $0.91(0.61$ to 1.33$)$ \\
\hline
\end{tabular}

${ }^{*}$ Cox proportional hazard model adjusted for age, cardiovascular disease, diabetes, and stroke.

A multidrug use model was used to examine whether participants who switched from angiotensin converting enzyme inhibitors to angiotensin receptor blockers, or the converse, adopted the dementia hazard rate for the subsequent drug. Participants were not excluded for using more than one drug type during the study. Participants were those without a previous diagnosis of dementia who were prescribed angiotensin receptor blockers or angiotensin converting enzyme inhibitors (but not both) and showed stable use of the drug over the first six months after entry into the study on the basis of a drug possession ratio of $80 \%$ or greater. All relevant drugs included in the Veteran Affairs health system formulary were used by the angiotensin converting enzyme inhibitors group. Participants who used angiotensin receptor blockers throughout the study or who started using angiotensin converting enzyme inhibitors and switched to angiotensin receptor blockers showed a significantly lower odds of incident dementia than the reference group that did not switch from angiotensin converting enzyme inhibitors throughout the study $(0.28,0.24$ to $0.32, \mathrm{P}<0.001$; table 5$)$. However, participants who initially received angiotensin receptor blockers but then switched to angiotensin converting enzyme inhibitors showed a non-significantly different risk of incident dementia than the reference group (table 5).

\section{Additive effects}

As angiotensin receptor blockers and angiotensin converting enzyme inhibitors both decrease signalling through the AT1 receptor, we hypothesised that their combined use might result in added inhibition, leading to enhanced clinical efficacy. We examined the effects of combined use on incident Alzheimer's disease or dementia among participants without a previous diagnosis of dementia, and on nursing home admissions among participants with pre-existing Alzheimer's disease or dementia. Combined use was generally associated with lower outcome rates than use of angiotensin receptor blockers alone, angiotensin converting enzyme inhibitor alone, or lisinopril alone (fig 2 and web extra table 5). For example, the hazard rate for the drug combination compared with angiotensin converting enzyme inhibitors alone for incident Alzheimer's disease was 0.45 ( 0.41 to $0.50, \mathrm{P}<0.001)$ and for dementia was 0.54 ( 0.51 to $0.57, \mathrm{P}<0.001$, fig 2 and web extra table 5). The hazard rate for admission to a nursing home among patients with dementia was 0.33 $(0.22$ to $0.49, \mathrm{P}<0.001)$ for combined use of angiotensin receptor blockers and angiotensin converting enzymes compared with lisinopril or any angiotensin converting enzyme inhibitor alone (fig 2 and web extra table 5).

\section{DISCUSSION}

This study suggests that angiotensin receptor blockers are associated with reduced incidence and progression of Alzheimer's disease and dementia compared with other drugs for cardiovascular disease or hypertension. One of the measures used for disease progression was admission to a nursing home. The robust reduction in such admissions associated with use of angiotensin receptor blockers is a particularly important observation that could have a major impact on public health if validated by future studies. The strength and consistency of the effect over several different analyses supports the validity of this finding.

Use of angiotensin receptor blockers was associated with a significant dose-response profile for incident dementia, with the brain penetrant angiotensin receptor blocker candesartan showing the strongest dose dependent reduction in incident dementia. Lisinopril, one of the main comparators, is not a brain penetrant, although whether brain penetration increases with dementia is unknown. ${ }^{41}$ However, when we compared the effects of angiotensin receptor blockers with that of the entire group of angiotensin converting enzyme inhibitors (see table 4), switching from angiotensin converting enzyme inhibitors to angiotensin receptor blockers was also associated with reductions in dementia. This suggests that selection bias linked to initial assignment of treatment with either drug class does not determine the outcome. Finally, both drug classes showed additive benefits, which is consistent with their mutual activity at the AT1 receptor. Additive effects were observed for lisinopril alone and for angiotensin converting enzyme inhibitors generally (fig 2 and web extra table 5). The additive benefits of both drug classes is consistent with recent prospective clinical trials. ${ }^{24}$ Combination therapy therefore could be particularly beneficial for patients.

For the study of incident Alzheimer's disease and dementia, we examined drugs using a "single drug" model that restricted drug classes to one particular group on entry and for the duration of the study. The other studies had fewer participants, which required use of a polypharmacy model to obtain sufficient power. In the polypharmacy model, use of lisinopril or angiotensin converting enzyme inhibitors was disallowed for participants in the angiotensin receptor blocker cohort entering the study; however, addition of either was allowed any time beyond six months after study entry. The rationale for the polypharmacy approach is that angiotensin receptor blockers might show a "gain of protection" compared with angiotensin converting enzyme inhibitors. The effects associated with additive drug use and with switching between the two drug classes (see tables 4 and 5) indicate that angiotensin receptor blockers are associated with better outcomes than use of angiotensin converting 


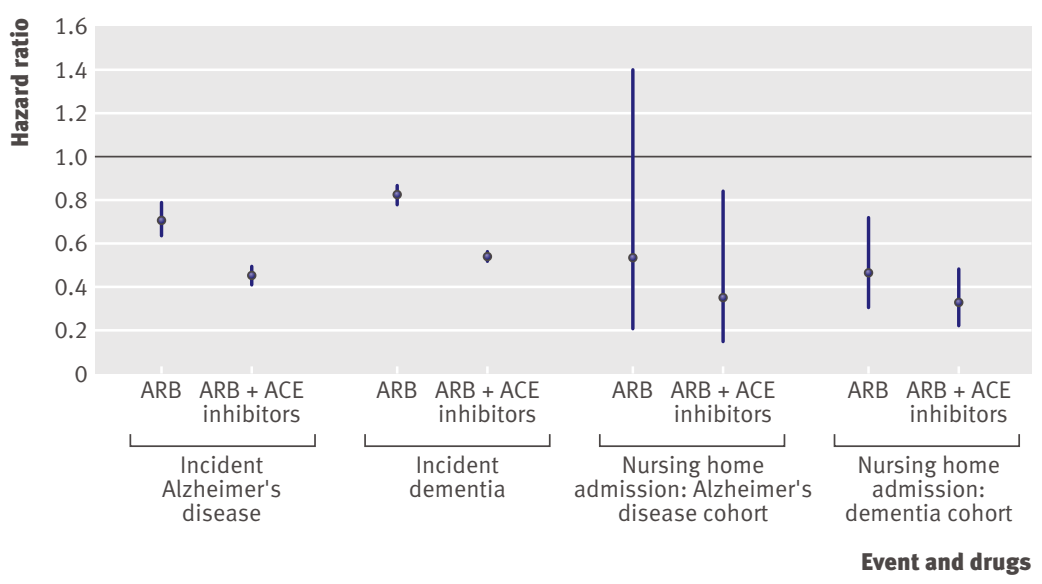

Fig 2 | Additive effects of angiotensin receptor blockers (ARB) and angiotensin converting enzyme (ACE) inhibitors compared with single drug use. Hazard rates $(95 \%$ confidence intervals) are adjusted for age, stroke, diabetes, and cardiovascular disease

enzyme inhibitors, as shown by the greater effect observed with a higher dose and with combined use of angiotensin receptor blockers and angiotensin converting enzyme inhibitors.

\section{Strengths and limitations of the study}

An important strength of our study was the use of comparators from the same class of drugs, which allowed cohorts that share similar demographic, health status, and hospital utilisation profiles to be compared. Our study covered a five year period. A longer time frame, however, might be associated with a more robust outcome because studies show that cardiovascular risk factors exert their impact on dementia beginning in mid-life. ${ }^{42-45}$

Misclassification, such as misdiagnosis or missing information, is an important factor that could bias the data. We compared rates of participants lost to followup in each cohort but observed no significant differences. We also included Alzheimer's disease and dementia as independent outcomes to control for problems with diagnostic sensitivity or specificity associated with population derived databases. In addition, misclassification would seem to bias towards the null hypothesis. Studies of population databases are prone to other unanticipated biases. Comorbidities might differ among the cohorts. Indeed, diabetes and stroke were significantly associated with some of the outcomes. However, such conditions are associated with higher rates of Alzheimer's disease and dementia, which would tend to decrease the size of any association of angiotensin receptor blockers with reduced rates of these diseases. Although we compared mean blood pressure between the groups (no differences were observed), we did not determine mean blood pressure lowering for angiotensin receptor blockers and angiotensin converting enzyme inhibitors. Studies have suggested that these drug classes achieve similar levels of blood pressure lowering, differences between the groups could contribute to the putative benefit towards dementia associated with angiotensin receptor blocker use. ${ }^{13}$ Multiple indication bias could dilute the effects of our findings but this would bias towards the null hypothesis. Under-diagnosis exists in the decision support system database, but our three cohorts had similar rates of hospital utilisation.

The open nature of the medical system in the United States also raises the possibility of a bias among participants using the Veterans Affairs healthcare system. One study showed high rates of use of the Veterans Affairs healthcare system by patients for primary health care and primary pharmacy sources. ${ }^{46}$ Our study incorporated losses to follow-up as an exclusion criterion, but omission of this from the model yielded similar outcomes, suggesting that only minor differences existed for source of healthcare use among the cohorts. Additional bias could come from several sources. Admission to a nursing home depends on factors that are independent of dementia, such as the ability of care givers to care for patients. Bias can also come from nursing home use, as participants can vary in their choice of nursing homes affiliated with the Veterans Affairs system or private systems. About half of the participants in the Veterans Affairs system choose nursing homes affiliated with the Veterans Affairs. ${ }^{47}$ Analysis of nursing home admissions on the basis of nursing homes affiliated with the Veterans Affairs

Table 5 |Effects of switching drug class on incidence of dementia

\begin{tabular}{lccc} 
Variables & Estimate (SE) & P value & Hazard rate* $(95 \% \mathrm{Cl})$ \\
\begin{tabular}{l} 
Variables: \\
\hline Angiotensin receptor blocker to angiotensin receptor blockert
\end{tabular} & $-0.73(0.018)$ & $<0.001$ & $0.48(0.47$ to 0.50$)$ \\
\hline Angiotensin receptor blocker to angiotensin converting enzyme inhibitor & $0.16(0.169)$ & 0.3562 & $1.17(0.84$ to 1.63$)$ \\
\hline Angiotensin converting enzyme inhibitor to angiotensin receptor blocker§ & $-1.28(0.073)$ & $<0.001$ & $0.28(0.24$ to 0.32$)$ \\
\hline Covariables: & $0.09(0.001)$ & $<0.001$ & $1.10(1.09$ to 1.10$)$ \\
\hline Age & $0.12(0.017)$ & $<0.001$ & $1.13(1.09$ to 1.17$)$ \\
\hline Cardiovascular disease & $0.28(0.016)$ & $<0.001$ & $1.33(1.29$ to 1.37$)$ \\
\hline Diabetes & $0.96(0.016)$ & $<0.001$ & $2.61(2.53$ to 2.69$)$
\end{tabular}

Reference group: angiotensin converting enzyme inhibitor to angiotensin converting enzyme inhibitor.

*Cox proportional hazard model adjusted for age, stroke, diabetes, and cardiovascular disease.

†Participants used angiotensin receptor blocker throughout study.

$\ddagger$ Participants switched from angiotensin receptor blocker to angiotensin converting enzyme inhibitor by end of study.

§Participants switched from angiotensin converting enzyme inhibitor to angiotensin receptor blocker by end of study. 


\section{WHAT IS ALREADY KNOWN ON THIS TOPIC}

Studies suggest that angiotensin receptor blockers offer superior protection against diabetes and possibly stroke compared with other antihypertensives

\section{WHAT THIS STUDY ADDS}

Angiotensin receptor blockers are associated with a reduced incidence of Alzheimer's disease and dementia

They are also associated with reduced rates of disease progression (admission to nursing homes and death) among people with Alzheimer's disease and dementia

Angiotensin receptor blockers seem to offer superior protection against Alzheimer's disease and dementia compared with other antihypertensives and cardiovascular drugs

system might introduce a general selection bias in our cohorts, but such bias needs to be assessed in the context of similar rates of losses to follow-up and use of cohorts based on similar drug classes that are also similar by other measures examined. Characterisation of bias in choice of nursing homes requires harmonisation of the Veterans Affairs and Medicare databases, which has not yet been achieved. Other unanticipated biases might also exist due to unmeasured variables, such as instrumental variables (for example, income, exercise). None the less, pharmacoepidemiological studies of drugs on risk of dementia need to be evaluated in large populations that permit adequate statistical power to control for confounding by indication. The present study is the first to compare both risk of dementia and progression of dementia in users of angiotensin receptor blockers compared with users of a drug from the same class (lisinopril) or users of other drugs prescribed for cardiovascular disease.

\section{Biological mechanisms}

Stroke was consistently ranked as the most important covariate in our dataset. The strong association of stroke with dementia and nursing home admission in our study is consistent with previous studies, suggesting the importance of vascular factors in progression of cognitive loss. ${ }^{48-50}$ Decreased cerebral blood flow is a common and early observation among people with Alzheimer's disease. ${ }^{49}$ Previous studies suggest that angiotensin receptor blockers offer an important advantage over angiotensin converting enzyme inhibitors and other antihypertensive agents in improving outcomes from stroke. ${ }^{751-53}$ Recent results from the Ongoing Telmisartan Alone and in Combination with Ramipril Global Endpoint Trial (ONTARGET), which examined the effects of telmisartan plus ramipril, observed a decrease in secondary stroke associated with use of telmisartan, but the lowering of stroke rates did not reach significance. ${ }^{54}$ Animal studies report that angiotensin receptor blockers elicit neuroprotective responses that are independent of decreases in blood pressure and are apparent even in cell culture. ${ }^{1852}$ Vascular dysfunction induced by amyloid $\beta$, the protein that accumulates in Alzheimer's disease, plays an important part in the disease. Loss of cerebral blood flow is a prominent and early feature of the disease, perhaps as a result of the accumulation of amyloid $\beta{ }^{495556}$ Angiotensin receptor blockers seem to be particularly effective at preventing vascular damage induced by amyloid $\beta{ }^{57-59}$ Because vascular dysfunction and stroke are associated with cognitive decline, our data raise the possibility that combined use of angiotensin receptor blockers and angiotensin converting enzyme inhibitors might confer superior protection against cognitive decline (compared with other cardiovascular drugs) by reducing neuronal damage associated with stroke and vascular dysfunction.

Diabetes is a strong risk factor for Alzheimer's disease and dementia, and diabetes was a significant covariate in our study. ${ }^{36061}$ Clinical studies also indicate that angiotensin receptor blockers offer superior protection against diabetes compared with other antihypertensive drugs. ${ }^{1323}$ Angiotensin receptor blocker mediated protection against deleterious effects of diabetes might also contribute to the positive results observed in this study. The biochemical mechanisms contributing to the putative beneficial clinical outcomes resulting from modulation of the renin-angiotensin system are difficult to identify and could be pleiotropic. Potential mechanisms are reviewed elsewhere. ${ }^{3233}$ Regardless of the mechanism, our study suggests that selective blockade of the angiotensin II receptor AT1 offers important health benefits to those with cognitive decline, and combined use of angiotensin receptor blockers and angiotensin converting enzyme inhibitors is associated with even greater benefits.

Contributors: $\mathrm{N}-\mathrm{CL}$ acquired and analysed the data, critically revised the manuscript, and provided technical support. AL and EL designed the study, acquired the data, did the statistical analysis, and critically revised the manuscript. RAW and MK interpreted the data and critically revised the manuscript for important intellectual content. LEK designed the study, analysed and interpreted the data, obtained funding, and critically revised the manuscript. BW conceived, designed, and supervised the study, analysed and interpreted the data, drafted the manuscript, and obtained funding. He is guarantor.

Funding: This work was supported by a grant award to BW from the Retirement Research Foundation and a donation from the Casten

Foundation. The researchers operate independently of the funders of the study

Competing interests: BW and RAW received a grant award from the Retirement Research Foundation to fund this research. BW received a donation from the Casten Foundation to fund this research.

Ethical approval: This study was approved by internal review boards of the Boston University School of Medicine, the Bedford Veterans Affairs Medical Center, and Jamaica Plains Veterans Affairs Medical Center. The study was based on administrative datasets and the participants were not identifiable to the authors.

Data sharing: No additional data available.

1 Whitmer RA, Sidney S, Selby J, Johnston SC, Yaffe K. Midlife cardiovascular risk factors and risk of dementia in late life. Neurology 2005;64:277-81.

2 Nash DT, Fillit H. Cardiovascular disease risk factors and cognitive impairment. Am J Cardiol 2006;97:1262-5.

3 Luchsinger JA, Reitz C, Honig LS, Tang MX, Shea S, Mayeux R. Aggregation of vascular risk factors and risk of incident Alzheimer disease. Neurology 2005;65:545-51.

4 Newman AB, Fitzpatrick AL, Lopez O, Jackson S, Lyketsos C, Jagust W, et al. Dementia and Alzheimer's disease incidence in relationship to cardiovascular disease in the Cardiovascular Health Study cohort. / Am Geriatr Soc 2005;53:1101-7.

5 Breteler MM, Claus IJ, Grobbee DE, Hofman A. Cardiovascula disease and distribution of cognitive function in elderly people: the Rotterdam Study. BMJ 1994;308:1604-8. 
6 Khachaturian AS, Zandi PP, Lyketsos CG, Hayden KM, Skoog I, Norton MC, et al. Antihypertensive medication use and incident Alzheimer disease: the Cache County Study. Arch Neurol 2006;63:686-92.

7 Skoog I, Lithell H, Hansson L, Elmfeldt D, Hofman A, Olofsson B, et al. Effect of baseline cognitive function and antihypertensive treatment on cognitive and cardiovascular outcomes: Study on COgnition and Prognosis in the Elderly (SCOPE). Am J Hypertens 2005;18:1052-9.

8 Forette F, Seux ML, Staessen JA, Thijs L, Babarskiene MR, Babeanu S, et al. The prevention of dementia with antihypertensive treatment: new evidence from the Systolic Hypertension in Europe (Syst-Eur) study. Arch Intern Med 2002;162:2046-52.

9 Qiu C, Winblad B, Fratiglioni L. The age-dependent relation of blood pressure to cognitive function and dementia. Lancet Neurol 2005;4:487-99.

10 Wolozin B, Kellman W, Ruosseau P, Celesia GG, Siegel G. Decreased prevalence of Alzheimer disease associated with 3-hydroxy-3methyglutaryl coenzyme A reductase inhibitors. Arch Neurol 2000;57:1439-43.

11 Jick H, Zornberg GL, Jick SS, Seshadri S, Drachman DA. Statins and the risk of dementia. Lancet 2000;356:1627-31.

12 Braunwald E, Domanski MJ, Fowler SE, Geller NL, Gersh BJ, Hsia J, et al. Angiotensin-converting-enzyme inhibition in stable coronary artery disease. N Engl J Med 2004;351:2058-68.

13 Matchar DB, McCrory DC, Orlando LA, Patel MR, Patel UD, Patwardhan MB, et al. Systematic review: comparative effectiveness of angiotensin-converting enzyme inhibitors and angiotensin II receptor blockers for treating essential hypertension. Ann Intern Med 2008;148:16-29.

14 Zaman MA, Oparil S, Calhoun DA. Drugs targeting the reninangiotensin-aldosterone system. Nat Rev Drug Discov 2002;1:621-36

15 Gallinat S, Yu M, Dorst A, Unger T, Herdegen T. Sciatic nerve transection evokes lasting up-regulation of angiotensin AT2 and AT1 receptor mRNA in adult rat dorsal root ganglia and sciatic nerves. Brain Res Mol Brain Res 1998;57:111-22.

16 Inagami T, Kambayashi Y, Ichiki T, Tsuzuki S, Eguchi S, Yamakawa T. Angiotensin receptors: molecular biology and signalling. Clin Exp Pharmacol Physiol 1999;26:544-9.

17 Stoll M, Steckelings UM, Paul M, Bottari SP, Metzger R, Unger T. The angiotensin AT2-receptor mediates inhibition of cell proliferation in coronary endothelial cells. J Clin Invest 1995;95:651-7.

18 Lucius R, Gallinat S, Rosenstiel P, Herdegen T, Sievers J, Unger T. The angiotensin II type 2 (AT2) receptor promotes axonal regeneration in the optic nerve of adult rats. J Exp Med 1998;188:661-70.

19 Ohrui T, Tomita N, Sato-Nakagawa T, Matsui T, Maruyama M, Niwa K, et al. Effects of brain-penetrating ACE inhibitors on Alzheimer disease progression. Neurology 2004;63:1324-5.

20 Rozzini L, Chilovi BV, Bertoletti E, Conti M, Del Rio I, Trabucchi M, et al. Angiotensin converting enzyme (ACE) inhibitors modulate the rate of progression of amnestic mild cognitive impairment. Int ) Geriatr Psychiatry 2006;21:550-5.

21 Parhofer KG, Munzel F, Krekler M. Effect of the angiotensin receptor blocker irbesartan on metabolic parameters in clinical practice: the DO-IT prospective observational study. Cardiovasc Diabetol 2007;6:36.

22 Andraws R, Brown DL. Effect of inhibition of the renin-angiotensin system on development of type 2 diabetes mellitus (meta-analysis of randomized trials). Am J Cardiol 2007;99:1006-12.

23 Elliott WJ, Meyer PM. Incident diabetes in clinical trials of antihypertensive drugs: a network meta-analysis. Lancet 2007;369:201-7.

24 Majani G, Giardini A, Opasich C, Glazer R, Hester A, Tognoni G, et al. Effect of valsartan on quality of life when added to usual therapy for heart failure: results from the Valsartan Heart Failure Trial. J Card Fail 2005;11:253-9.

25 Weir RA, McMurray JJ, Puu M, Solomon SD, Olofsson B, Granger CB, et al. Efficacy and tolerability of adding an angiotensin receptor blocker in patients with heart failure already receiving an angiotensin-converting inhibitor plus aldosterone antagonist, with or without a beta blocker. Findings from the Candesartan in Heart failure: Assessment of Reduction in Mortality and Morbidity (CHARM)-Added trial. Eur J Heart Fail 2008;10:157-63.

26 Hanon O, Berrou JP, Negre-Pages L, Goch JH, Nadhazi Z, Petrella R, et al. Effects of hypertension therapy based on eprosartan on systolic arterial blood pressure and cognitive function: primary results of the Observational Study on Cognitive function And Systolic Blood Pressure Reduction open-label study. J Hypertens 2008;26:1642-50.

27 Raghavendra V, Chopra K, Kulkarni SK. Involvement of cholinergic system in losartan-induced facilitation of spatial and short-term working memory. Neuropeptides 1998;32:417-21.

28 Raghavendra V, Chopra K, Kulkarni SK. Comparative studies on the memory-enhancing actions of captopril and losartan in mice using inhibitory shock avoidance paradigm. Neuropeptides 2001;35:65-9.
29 Fogari R, Mugellini A, Zoppi A, Derosa G, Pasotti C, Fogari E, et al. Influence of losartan and atenolol on memory function in very elderly hypertensive patients. J Hum Hypertens 2003;17:781-5.

30 Tedesco MA, Ratti G, Mennella S, Manzo G, Grieco M, Rainone AC, et al. Comparison of losartan and hydrochlorothiazide on cognitive function and quality of life in hypertensive patients. Am J Hypertens 1999;12:1130-4.

31 Poon IO. Effects of antihypertensive drug treatment on the risk of dementia and cognitive impairment. Pharmacotherapy 2008;28:366-75.

32 Kehoe PG, Wilcock GK. Is inhibition of the renin-angiotensin system a new treatment option for Alzheimer's disease? Lancet Neurol 2007;6:373-8.

33 Kehoe PG, Miners S, Love S. Angiotensins in Alzheimer's diseasefriend or foe? Trends Neurosci 2009;32:619-28.

34 Smith MW, Joseph GJ. Pharmacy data in the VA health care system. Med Care Res Rev 2003;60:92-123S.

35 Levey AS, Bosch JP, Lewis JB, Greene T, Rogers N, Roth D. A more accurate method to estimate glomerular filtration rate from serum creatinine: a new prediction equation. Modification of Diet in Renal Disease Study Group. Ann Intern Med 1999;130:461-70.

36 Stern Y, Albert M, Brandt J, Jacobs DM, Tang MX, Marder K, et al. Utility of extrapyramidal signs and psychosis as predictors of cognitive and functional decline, nursing home admission, and death in Alzheimer's disease: prospective analyses from the Predictors Study. Neurology 1994;44:2300-7.

37 Smith F, Talwalker S, Gracon S, Srirama M. The use of survival analysis techniques in evaluating the effect of long-term tacrine (Cognex) treatment on nursing home placement and mortality in patients with Alzheimer's disease. J Biopharm Stat 1996;6:395-409.

38 Stern Y, Tang MX, Albert MS, Brandt J, Jacobs DM, Bell K, et al. Predicting time to nursing home care and death in individuals with Alzheimer disease. JAMA 1997;277:806-12.

39 Geldmacher DS, Provenzano G, McRae T, Mastey V, leni JR. Donepezil is associated with delayed nursing home placement in patients with Alzheimer's disease. J Am Geriatr Soc 2003;51:937-44.

40 Aisen PS, Schafer KA, Grundman M, Pfeiffer E, Sano M, Davis KL, et al. Effects of rofecoxib or naproxen vs placebo on Alzheimer disease progression: a randomized controlled trial. JAMA 2003;289:2819-26

41 Ranadive SA, Chen AX, Serajuddin AT. Relative lipophilicities and structural-pharmacological considerations of various angiotensinconverting enzyme (ACE) inhibitors. Pharm Res 1992;9:1480-6.

42 Launer LJ, Ross GW, Petrovitch H, Masaki K, Foley D, White LR, et al. Midlife blood pressure and dementia: the Honolulu-Asia aging study. Neurobiol Aging 2000;21:49-55.

43 Sjogren M, Mielke M, Gustafson D, Zandi P, Skoog I. Cholesterol and Alzheimer's disease-is there a relation? Mech Ageing Dev 2006;127:138-47

44 Kivipelto M, Helkala EL, Laakso MP, Hanninen T, Hallikainen M, Alhainen $\mathrm{K}$, et al. Midlife vascular risk factors and Alzheimer's disease in later life: longitudinal, population based study. BMJ 2001;322:1447-51.

45 Kivipelto M, Ngandu T, Laatikainen T, Winblad B, Soininen $H$ Tuomilehto J. Risk score for the prediction of dementia risk in 20 years among middle aged people: a longitudinal, populationbased study. Lancet Neurol 2006;5:735-41.

46 Hamed A, Lee A, Ren XS, Miller DR, Cunningham F, Zhang H, et al. Use of antidepressant medications: are there differences in psychiatric visits among patient treatments in the Veterans Administration? Med Care 2004;42:551-9.

47 Kinosian B, Stallard E, Wieland D. Projected use of long-term-care services by enrolled veterans. Gerontologist 2007;47:356-64.

48 De la Torre JC. Is Alzheimer's disease a neurodegenerative or a vascular disorder? Data, dogma, and dialectics. Lancet Neurol 2004;3:184-90.

49 Ruitenberg A, den Heijer T, Bakker SL, van Swieten JC, Koudstaal PJ, Hofman A, et al. Cerebral hypoperfusion and clinical onset of dementia: the Rotterdam Study. Ann Neurol 2005;57:789-94.

50 Encinas M, De Juan R, Marcos A, Gil P, Barabash A, Fernandez C, et al. Regional cerebral blood flow assessed with 99 mTc-ECD SPET as a marker of progression of mild cognitive impairment to Alzheimer's disease. Eur J Nucl Med Mol Imaging 2003;30:1473-80.

51 Thone-Reineke C, Steckelings UM, Unger T. Angiotensin receptor blockers and cerebral protection in stroke. J Hypertens Suppl 2006;24:115-21S

52 Wilms H, Rosenstiel P, Unger T, Deuschl G, Lucius R. Neuroprotection with angiotensin receptor antagonists: a review of the evidence and potential mechanisms. Am J Cardiovasc Drugs 2005;5:245-53.

53 Krikov M, Thone-Reineke C, Muller S, Villringer A, Unger T. Candesartan but not ramipril pretreatment improves outcome after stroke and stimulates neurotrophin BNDF/TrkB system in rats. J Hypertens 2008;26:544-52. 
54 Yusuf S, Teo KK, Pogue J, Dyal L, Copland I, Schumacher H, et al. Telmisartan, ramipril, or both in patients at high risk for vascular events. N Engl J Med 2008;358:1547-59.

55 Prohovnik I, Mayeux R, Sackeim HA, Smith G, Stern Y, Alderson PO. Cerebral perfusion as a diagnostic marker of early Alzheimer's disease. Neurology 1988;38:931-7.

56 Niwa K, Porter VA, Kazama K, Cornfield D, Carlson GA, Iadecola C. A beta-peptides enhance vasoconstriction in cerebral circulation. $\mathrm{Am}$ Physiol Heart Circ Physiol 2001;281:H2417-24.

57 Takeda S, Sato N, Takeuchi D, Kurinami H, Shinohara M, Niisato K, et al. Angiotensin receptor blocker prevented \{beta\}-amyloidinduced cognitive impairment associated with recovery of neurovascular coupling. Hypertension 2009;54:1345-52.

58 Tsukuda K, Mogi M, Iwanami J, Min LJ, Sakata A, Jing F, et al. Cognitive deficit in amyloid-beta-injected mice was improved by pretreatment with a low dose of telmisartan partly because of peroxisome proliferator-activated receptor-gamma activation. Hypertension 2009;54:782-7.

59 Wang J, Ho L, Chen L, Zhao Z, Zhao W, Qian X, et al. Valsartan lowers brain beta-amyloid protein levels and improves spatial learning in a mouse model of Alzheimer disease. J Clin Invest 2007;117:3393-402.

60 Biessels GJ, Kappelle LJ. Increased risk of Alzheimer's disease in type II diabetes: insulin resistance of the brain or insulin-induced amyloid pathology? Biochem Soc Trans 2005;33:1041-4.

61 In't Veld BA, Ruitenberg A, Hofman A, Stricker BH, Breteler MM. Antihypertensive drugs and incidence of dementia: the Rotterdam Study. Neurobiol Aging 2001;22:407-12.

Accepted: 26 October 2009 